Soffia Jónasdóttir

pediatric endocrinologist, attending at University Hospital Iceland, Childen's Hospital

https://doi.org/10.17992/lbl.2017.09.147

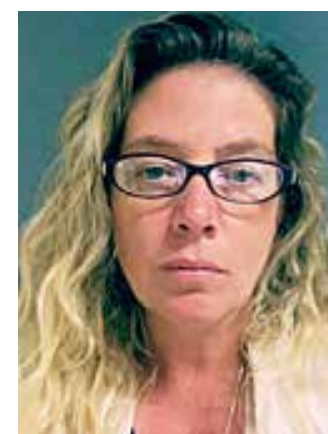

\section{Soffía Jónasdóttir}

sérfræðingur í hormóna- og efnaskiptasjúkdómum barna, barnalæknir Landspítala

\title{
D-vítamín - gott fyrir alla
}

Á síðustu árum hefur D-vítamín hlotið aukna athygli par sem fjöldi rannsókna hefur sýnt fram á mun flóknara samspil pess við starfsemi líkamans en einungis áhrif 1,25 D á frásog kalks í görn og uppbyggingu beina. Niðurstöður virðast tengja skort á D-vítamíni við meingerð hinna ýmsu sjúkdóma. Pannig er mögulegt að notkun D-vítamíns geti verið fyrirbyggjandi í sjúkdómum eins og sykursýki af gerð I og II, Chrons, háprýstingi og MS. Nýleg meta-analýsa sýndi tengsl milli D-vítamíngjafar á fyrstu mánuðum ævinnar og lægri tíðni á sykursýki af gerð I síðar á ævinni¹. D-vítamínviðtakar finnast bæði í hjartafrumum og sléttum vöðvafrumum æðakerfisins. Skortur á Dvítamíni hefur í rannsóknum tengst aukinni áhættu hækkaðs blóðprýstings, hjartaáfalls og heilablóðfalls. Tengsl D-vítamínskorts við aukna tíðni efri öndunarfærasýkinga, asthma og exems, meðal barna hafa komið fram í nokkrum rannsóknum.

Í pessu tölublaði er áhugaverð grein par sem Pórunn Hannesdóttir og félagar birta niðurstöður rannsóknar sem kannaði tengsl D-vítamíngilda í íslenskum skólabörnum við pekkta áhættupætti hjarta- og æðasjúkdóma, jafnframt pví að meta tengsl við líkamspyngdarstuðul barnanna².

McDonald og félagar sýndu svipaðar niðurstöður par sem 76\% barna á aldrinum 2 - 18 ára sem voru til meðferðar vegna ofpyngdar/offitu voru með D-vítamíngildi undir viðmiðunargildum, 32\% peirra voru með hækkaðan blóðprýsting. D-vítamíngildi yfir 50 nmól/L var tengt lægra insúlíngildi (15,8 (11,7 - 23,1) mU/L vs. 21,1 (14,3 - 34,2) mU/L, lægra insúlínviðnámi (HOMA-IR 3,5 (2,5 - 4,9) vs. 4,8 (3,1 - 6,9) og lægri systólískum blóðprýstingi $(73,0 \pm 25,8 \text { vs. } 80,6 \pm 17,0 ; p=0,04)^{3}$.

Ofpyngd er ekki talin trufla nýmyndun á D-vítamíni í húð. D-vítamín er fitusækin sameind og hjá einstaklingum í yfirpyngd er aukinn hluti D-vítamínforðans geymdur í fituvef. Petta er talið valda lægra D-vítamíngildi í sermi hjá ofpungum einstaklingum. Margir telja pví að einstaklingar í of pyngd purfi tvöfaldan skammt D-vítamíns miðað við almennar ráðleggingar til aldurshópsins til að viðhalda eðlilegum gildum í sermi.

Lágt D-vítamíngildi meðal ofpungra barna er talið af mörgum endurspegla í raun einhæft mataræði; pau sleppa morgunmat, drekka ekki mjólk en frekar ávaxtasafa, borða áberandi meira kolvetni og lítið af fiski. Nánast undantekningalaust mælist lágt D-vítamíngildi hjá íslenskum börnum sem leitað er með til innkirtlalæknis vegna of pyngdar (Líkamspyngdarstuðull yfir 85 persentíl).

Á síðustu árum hefur orðið aukning í greiningum á beinkröm meðal ungra barna á Íslandi. Í flestum tilfellum eru pað börn sem eru á sérfæði vegna ofnæmis eða ópols, oft á tíðum með mjög takmarkaðri kalkinntöku par sem mjólkurvörur skortir. D-vítamíngjöf meðal barna er oft mun minni en talið er og ráðlagt er. Gjöf D-vítamíns er oft hætt vegna magaópæginda ungbarna. Dagheimili og dagforeldrar hafa í mörgum tilfellum sinnt lýsisgjöf íslenskra barna, sem síðan hættir pegar leikskólagöngu lýkur par sem foreldrar hafa ekki tileinkað sér að gefa börnum sínum lýsi og vítamín.

Almennt fæði er fátæklegt af náttúrulegu D-vítamíni. Íslendingar hafa verið mikil fiskipjóð en ein algengasta fisktegundin sem börn borða á Íslandi, ýsa, er nokkuð snauð af D-vítamíni. Lax, túnfiskur, makríll og lúđa eru fisktegundir ríkar af D-vítamíni. Einnig má nefna vítamínbætt morgunkorn og nú mjólk sem er sérstaklega D-vítamínbætt. Ísland teldist seint til suðrænna sólarparadísa, en áhugavert er að sjá að jafnvel í hinum suðrænu löndum er D-vítamínskortur meðal barna algengur. Sólarvörn með SPF 30 minnkar nýmyndun D-vítamíns í húð um 95-99\% en mikilvægi pess að vernda húðina er óumdeilt.

Ráðlagður dagskammtur hérlendis fyrir D-vítamín er nú 15 míkrógrömm ( $\mu \mathrm{g})(600 \mathrm{AE})$ fyrir aldurshópinn 10 til 70 ára, en $20 \mu \mathrm{g}(800 \mathrm{AE})$ fyrir fólk yfir sjötugt. Fyrir börn yngri en 10 ára og ungbörn eru ráðlögð $10 \mu \mathrm{g}(400 \mathrm{AE})$ á dag${ }^{4}$.

Ein teskeið ( $5 \mathrm{ml}$ ) af krakkalýsi inniheldur 9,2 $\mu \mathrm{g}$ (368 AE) af D-vítamíni og 1 teskeið af porskalýsi $10 \mu \mathrm{g}$. (400 AE). Í landskönnun á mataræði 6 ára íslenskra barna frá 2011-2012 kom fram að einungis fjórðungur barnanna fékk ráðlagðan dagskammt eða meira af D-vítamíni (sá fjórðungur barna sem tók lýsi) og var D-vítamíninntaka fjórðungs barna undir lágmarkspörf $(2,5 \mu \mathrm{g} / \mathrm{dag})^{5}$. Peir Íslendingar sem ekki taka inn aukalega D-vítamín fá að meðaltali 4-5 $\mu$ g daglega úr fæðu.

Árið 2011 gáfu samtök bandarískra innkirtlalækna (Endocrine Society) út ráđleggingar um D-vítamínskammta par sem æskileg serumgildi D-vítamíns voru ráðlögð yfir 75 nmól/L til að til að viðhalda eðlilegu jafnvægi í efnaskiptum kalks, beina og vöðva. Til pess að viðhalda serumgildum 25(OH)D yfir 75 nmól/L parf fullorðinn einstaklingur 1,500-2,000 AE daglega af D-vítamíni en börn og unglingar í pað minnsta 1,000 AE/ dag. Ekki hafa verið gefin út sérstök viðmið vegna hugsanlegra annarra áhrifa D-vítamíns ${ }^{6}$.

คаð gætir pví nokkurs misræmis í ráđleggingum um D-vítamín skammta með tilliti til pess hvað teljist eðlileg serumgildi, en undir 30 nmól/L er oftast talið skortur, 30 - 50 nmól/L ónóg og eðlileg gildi 50 150 nmól/L, samanber viðmið D-vítamín-mælinga á Landspítala. Aðrir vilja miða við að allt undir 50 nmól/L sé skortur.

D-vítamínskortur á Íslandi er mun meiri en talið er bæði meðal barna og fullorðinna eins og Gunnar Sigurðsson og félagar hafa áður birt. Nú pegar sumri tekur að halla er mikilvægt að vekja upp umræðuna um mikilvægi D-vítamíngjafar og er grein Pórunnar og félaga mikilvæg í peirri umræðu.

\section{Heimildir:}

1. MacDonald K, Godziuk K, Yap J, LaFrance R, Ansarian M, Haqq A, Mager DR. J Pediatr Gastroenterol Nutr. 2017 Apr 27.

2. Pórunn Hannesdóttir. Hannes Hrafnkelsson, Erlingur Jóhannsson, Emil L. Sigurðsson. Tengsl D-vítamíns og áhættupátta hjarta- og æðasjúkdóma meðal íslenskra barna. Læknablaðið 2017/103

3. Ingibjörg Gunnarsdóttir, Hafdís Helgadóttir, Birna Pórisdóttir og Inga Pórsdóttir. Landskönnun á mataræði sex ára barna 2011-2012. Læknablaðið 2013/99

4. An increase in serum 25-hydroxyvitamin $\mathrm{D}$ concentrations preceded a plateau in type 1 diabetes incidence in Finnish children. Nov;99(11):E2353-6. doi: 10.1210/jc.2014-1455.

5. https://ods.od.nih.gov/factsheets/VitaminD-HealthProfessional/

6. Wagner CL, Greer FR; AAP Section on Breastfeeding; American Academy of Pediatrics Committee on Nutrition. Prevention of rickets and vitamin D deficiency in infants, children, and adolescents. Pediatrics 2008;122:1142-1152. 